\title{
Editorial
}

\section{Abrindo as fronteiras da avaliação}

Estamos em tempo de interdisciplinaridade no campo da avaliação. São os grandes estudiosos da atualidade que apontam para a urgência de expandir a avaliação do domínio tradicionalmente exclusivo da educação, para além das fronteiras do conhecimento, de modo a assegurar sua presença em todos os setores e níveis de reflexão e atuação. É nesse sentido que a avaliação se faz transdisciplinar não só pela exigência de sua própria natureza, como também pela necessidade de se utilizar suas potencialidades para o bem social. Essa arrojada penetração da avaliação nas diferentes áreas disciplinares requer contudo, como alertam aqueles estudiosos e como reafirmam os que praticam a avaliação, o respeito às limitações que provém das culturas, das condições políticas, das situações econômicas e sobretudo dos valores que norteiam o objeto - foco da avaliação em questão. Assim, o direito de ir e vir na transposição das fronteiras do mundo teórico-acadêmico metodológico e prático da avaliação terá que ser fortificado e experimentado, mas conduzido até onde aqueles limites o permitirem. É nessa capacidade de articular eticamente forças positivas e contrárias que reside um dos mais notáveis desafios da avaliação contemporânea.

Não resta a menor dúvida de que nesse ponto crucial se impõe a premência da formação de avaliadores profissionais com a criatividade e a capacidade de, continuamente, estarem inventando novos meios de avaliar, novas posturas de atuar e novas idéias, para elevarem a avaliação aos patamares mais significativos de integração do conhecimento e de flexibilidade no trabalho, autenticamente participativo, em união com todos os envolvidos na missão de avaliar para transformar e aperfeiçoar.

A Fundação Cesgranrio está plenamente consciente desta responsabilidade e acata os movimentos ascensionais de uma tal trajetória.

\section{Carlos Alberto Serpa de Oliveira}

